\title{
MENINGKATKAN KEDISIPLINAN BELAJAR MELALUI BIMBINGAN KELOMPOK TEKNIK PROBLEM SOLVING SISWA SMA
}

\author{
Fitria Febriyani, Bambang Susanto, Muhammad Arief Maulana
}

Program Studi Bimbingan dan Konseling, Universitas Veteran Bangun Nusantara Email: Fitriafebriyani6@gmail.com

\begin{abstract}
Article Info
Available online

31.12.2019

Tujuan dalam penelitian ini adalah untuk meningkatkan kedisiplinan belajar Siswa kelas XI IPS Sekolah Menengah Atas Veteran 1 Sukoharjo Tahun Pelajaran 2019/2020. Jenis penelitian ini adalah penelitian tindakan bimbingan dan konseling. Metode pengumpulan data menggunakan metode observasi, angket dan dokumentasi. Sedangkan metode analisis data menggunakan statistik deskriptif, berdasarkan teknik prosentase untuk membandingkan kedisiplinan belajar siswa dari pra siklus, siklus I, siklus II. Apabila hasil evaluasi menunjukkan adanya peningkatan kedisiplinan belajar dan sudah mencapai indikator kinerja, maka penelitian tindakan ini dinyatakan telah berhasil dan dapat dihentikan. Dari perolehan data pra siklus, 8 siswa subjek penelitian memperoleh skor 92 dengan persentase $61 \%$ masuk dalam kategori cukup baik. Perbaikan pada siklus I memperoleh skor 103 dengan persentase 69\% dengan kategori baik. Perbaikan pada siklus II memperolah skor 121 dengan persentase $81 \%$ masuk dalam kategori baik. Sedangkan hasil observasi pada pra siklus, siswa memperoleh persentase $35 \%$ dengan kategori kurang baik. Setelah perbaikan siklus I siswa memperoleh persentase $48 \%$ dengan kategori cukup baik dan perbaikan siklus II memperolah persentase $68 \%$ dengan kategori baik.
\end{abstract}

Kata kunci: Layanan Bimbingan Kelompok, Teknik Problem Solving dan Kedisiplinan Belajar.

\section{Abstract}

The purpose of this research is improving student learning discipline in class XI IPS at Sukoharjo Veteran 1 High School Academic Year 2019/2020. This type of research is guidance and counseling action research. method of collecting data using observation method, questionnaire and documentation. While method of analyzing data using descriptive statistics, based presentation technique to compare student learning discipline from pre cycle, cycle I, cycle II. If the evaluation result to show an increase in learning discipline has reached performance indicators, then this action research was declared successful and can be stopped. From the precycle data acquisition, 8 students of research subjects get a score of 92 with a presentation of $61 \%$ included in the quite good category. Improvements in cycle I gained a score of 103 with a presentation of $69 \%$ with good category. The improvement in cycle II get score of 121 with a presentation of $81 \%$ included in the good category. While the results of observation in the precycle, students get a presentation of $35 \%$ with the category of less good. After the improvement in cycle I students get a presentation of $48 \%$ with good enough category and the improvement cycle II get a percentage of $68 \%$ with a good category.

Keywords: Group Guidance Service, Problem Solving Technique and Learning Discipline.

\section{PENDAHULUAN}

Kedisiplinan masih menjadi masalah di dunia pendidikan. Kedisiplinan siswa dapat dilihat dari kepatuhan siswa terhadap aturan tata tertib yang berkaitan dengan jam belajar di sekolah meliputi jam masuk sekolah dan keluar sekolah, kepatuhan siswa dalam berpakaian, kepatuhan siswa dalam mengikuti kegiatan sekolah, dan lain sebagainya. Guru memberikan hukuman kepada siswa dengan alasan untuk mendisiplinkan siswa, akan tetapi orangtua siswa tidak terima sehingga mendatangi sekolah yang bersangkutan untuk meminta pertanggung jawaban. Bahkan ada yang melaporkan ke 
pihak berwajib. Bagaimana tujuan pendidikan nasional itu bisa terwujud jika saling mengkambinghitamkan satu sama lain.

Aliya (2011: 1) dari kasus-kasus yang ada dapat diambil kesimpulan bahwa penerapan disiplin kepada anak belum bisa diterapkan secara penuh, karena belum bertemunya cara yang cocok untuk menerapkannya. Secara sederhana, disiplin dapat dimaknai sebagai kepatuhan pada peraturan baik lisan maupun tulisan, baik di lingkungan keluarga, masyarakat, maupun sekolah. Sekolah sebagai lembaga pendidikan berbeda-beda dalam memaknai kedisiplinan. Perbedaan pemahaman ini memunculkan konflik yang berkepanjangan sehingga banyak kasus kedisiplinan yang berupa kekerasan masuk ke ranah hukum. Terbukti dngan banyaknya kasus yang diliput dalam beberapa media masa. Pihak-pihak yang bersangkutan bersikeras bahwa langkah yang mereka lakukan adalah benar dan sesuai aturan. Guru merasa bahwa hukuman yang dalam hal ini banyak disebut dengan kekerasan perlu diberikan kepada siswa untuk menumbuhkan disiplin yang tinggi dengan tidak melampaui batas-batas yang masuk kategori kekerasan. Sedangkan orang tua berpendapat bahwa kekerasan dalam bentuk apapun dalam kedok hukuman, tidak dapat dilakukan apalagi di dunia pendidikan.

Guru memahami kedisiplinan dengan mengabsahkan penggunaan kekerasan atau hukuman, dengan landasan bahwa yang terjadi di sekolah itu harus sesuai dengan yang diatur oleh pengelola lembaga pendidikan itu sendiri. Dengan demikian siswa merasa leluasa dalam melakukan pelanggaran-pelanggaran disekolah karena mereka merasa ada pembelaan dari beberapa pihak. Terbukti banyaknya fakta yang menyatakan pelaporan kepada pihak kepolisian tentang kekerasan yang dilakukan oleh guru. Perbedaaan itu tidak terselesaikan, sehingga dalam banyak kasus muncul konflik yang tidak sependapat mengenai kedisiplinan, padahal, kedisiplinan sangat penting dalam menunjang keberhasilan pendidikan di sekolah, dalam proses pelaksanaan pendidikan.

Aliya (2011: 4) kedisiplinan sangat diperlukan dan salah satu faktor yang cukup dominan, karena tanpa disertai dengan kedisiplinan maka seluruh kegiatan yang ada pada suatu kelompok mustahil akan bisa tercapai tujuan akhir kelompok tersebut. Dalam proses pembelajaran, kedisiplinan siswa merupakan salah satu faktor terpenting yang sangat menentukan keberhasilan termasuk di dalamnya adalah pendidikan. Setiap lembaga pendidikan atau masing-masing guru mempunyai cara untuk melaksanakan kedisiplinan. Disiplin terbukti membuat tingkat kesuksesan lebih tinggi, beberapa tokoh yang sukses banyak dididik dengan menerapkan kedisiplinan yang ketat.

Jika masih ada yang mempunyai anggapan bahwa sukses bisa diraih tanpa disiplin berarti orang itu sedang melamun, disiplin merupakan faktor dominan yang menjadi syarat mutlak memperoleh kesuksesan. Kesuksesan belajar sebenarnya tidak terlepas dari kedisiplinan siswa, siswa dikatakan 
disiplin dalam belajar apabila telah terbiasa melakukan kegiatan belajar tepat waktu, tempat, dan menurut peraturan-peraturan yang ada. Untuk membentuk kedisiplinan siswa perlu disusun tata tertib yang mengikat berikut dengan sanksi jika melanggarnya agar terbiasa melakukan sesuatu yang sesuai dengan aturan yang ada, sehingga dengan kebiasaan mentaati tata tertib akan tertanam nilai kedisiplinan dalam diri siswa.

Peneliti melihat beberapa masalah kedisiplinan yang muncul di SMA Veteran 1 Sukoharjo. Diantaranya adalah siswa terlambat saat masuk sekolah, membolos saat pelajaran maupun tidak masuk tanpa keterangan, saat jam masuk kelas siswa masih diluar kelas, menyontek, dan mengerjakan tugas tidak tepat waktu. Digunakan layanan bimbingan kelompok karena menurut Rosidah (2016: 138) bimbingan kelompok secara konseptual dinilai efektif dalam memberikan tindakan-tindkan positif kepada siswa. Sifat dari bimbingan kelompok itu sendiri yang bersifat informatif dapat digunakan untuk memberikan informasi baru kepada anggota kelompok yang berhubungan dengan permasalahan kedisiplinan belajar. Dalam penelitian ini menggunakan bimbingan kelompok dengan teknik problem solving. Menurut Wibowo, dkk ( 2019: 48) tujuan layanan bimbingan kelompok adalah untuk membantu memecahkan masalah-masalah umum yang sedang dihadapi siswa secara mandiri, melatih siswa dalam mengembangkan kemampuan bersosialisasi serta meningkatkan kemampuan berkomunikasi verbal dan non-verbal, sehingga siswa mampu berinteraksi dengan baik, mengemukakan pendapatnya sendiri dan tidak sekedar mengikuti pendapat orang lain.

Teknik problem solving digunakan karena menurut Piaget dalam Santrock (2003: 108) menjelaskan bahwa remaja pada usia 11 sampai dengan 15 tahun sudah mampu membayangkan situasi rekaan dan mencoba mengolahnya dengan pemikiran logis, dan memungkinkan remaja tersebut trampil dalam menentukan penyelesaian masalahnya sendiri tanpa bergantung pada orang lain. Hal tersebut dapat dilakukan dengan terbiasanya siswa dalam memecahkan permasalahan yang dialami sehingga siswa tersebut mampu membentuk suatu konsep pemikiran positif yang dapat dijadikan sebagai suatu patokan dalam membangun kemampuan penyesuaian dirinya dengan baik.

Teknik problem solving atau pemecahan masalah ini digunakan dengan tujuan untuk menuntun siswa pada proses berpikir kritis, berpikir analitis, berpikir reflektif, pengembangan daya nalar pada proses cara-cara pemecahan masalah, dan mampu mengambil keputusan secara tepat bagi dirinya. Maka untuk memotivasi siswa dalam meningkatkan kedisiplinan siswa perlu diadakannya bimbingan kelompok dengan teknik problem solving.

Melalui bimbingan kelompok dengan teknik problem solving diharapkan semua anggota kelompok dapat menggungkapkan masalahnya dan diselesaikan bersama melalui teknik pemecahan masalah (problem solving). Disinilah anggota dan peneliti mencari penyebab siswa tidak disiplin dan kemudian mencari solusi bersama yang sesuai dengan anggota kelompok. Berdasarkan uraian latar 
belakang diatas maka perlu diadakan penelitian mengenai kedisiplinan belajar siswa dalam kegiatan belajar mengajar dengan mengambil judul "Upaya Meningkatkan Kedisiplinan Belajar Melalui Bimbingan Kelompok Dengan Teknik Problem Solving Pada Siswa Kelas XI IPS Sekolah Menengah Atas Veteran 1 Sukoharjo Tahun 2019/2020”.

\section{METODE PENELITIAN}

Jenis penelitian ini adalah penelitian Tindakan Bimbingan dan Konseling (PTBK). Proses penelitian berbentuk siklus mengacu pada model Kemmis dan Mc Taggart. Penelitian ini terdiri dari dua siklus, masing masing siklus melalui tahap perencanaan tindakan, pelaksanaan tindakan, observasi dan refleksi. Adapun peneliti bertindak sebagai pelaksana pembelajaran, observasi, pengumpul data, penganalisis data dan pelapor hasil penelitian. Menurut Arikunto (2010: 197) teknik pengumpulan data adalah usaha sadar untuk mengumpulkan data yang dilakukan secara sistematis dengan prosedur berstandar. Teknik pengumpulan data adalah cara yang dipergunakan oleh peneliti untuk mengumpulan data sesuai dengan bentuk penelitian tindakan dalam bimbingan konseling, juga sumber data yang dimanfaatkan. Maka metode pengumpulan data yang peneliti gunakan pada penelitian ini adalah angket, observasi dan dokumentasi. Analisis data dilakukan dengan metode statistik deskriptif berdasarkan teknik prosentase untuk membandingkan kedisiplinan belajar ssiswa dari pra siklus, siklus I, siklus II. Apabila hasil evaluasi menunjukkan adanya peningkatan kedisiplinan belajar dan sudah mencapai indikator kinerja, maka penelitian tindakan ini dinyatakan telah berhasil dan dapat dihentikan.

\section{PEMBAHASAN}

\section{Pra Siklus}

Pada pra siklus terdapat 13 siswa yang kedisiplinan belajarnya masuk dalam kategori baik, dan 18 siswa yang kedisiplinan belajarnya masuk dalam kategori cukup baik. Dan 1 siswa masuk dalam kategori kurang baik. Diambil 8 siswa yang memiliki skor dan kategori paling rendah sebagai subyek penelitian. 8 siswa tesebut yang akan diberikan layanan bimbingan kelompok teknik problem solving.

\section{Siklus I}

Setelah diberikan layanan bimbingan kelompok dengan teknik problem solving siklus I diperoleh hasil perhitungan angket dan observasi 8 siswa subjek penelitian memperoleh skor angket kedisiplinan belajar dengan rata-rata 92 dan persentase $61 \%$ dengan kategori cukup baik. Dan memperoleh skor rata-rata lembar observasi 7 dan persentase 35\% dengan kategori kurang baik. 


\section{Siklus II}

Setelah diberikan layanan bimbingan kelompok dengan teknik problem solving siklus II diperoleh hasil perhitungan angket dan observasi peneliti memperoleh hasil angket kedisiplinan belajar siswa dengan skor rata-rata 121 dengan persentase $81 \%$ dengan kategori baik. Sedangkan dalam perhitugan lembar observasi 8 subjek memperoleh skor rata-rata 14 dan persentase $68 \%$ dengan kategori baik.

Tabel.1

Perbandingan Skor Angket Pra Siklus, Siklus I, Siklus II

\begin{tabular}{clllllll}
\hline No & Nama Siswa & \multicolumn{2}{c}{ Pra Siklus } & \multicolumn{2}{c}{ Siklus 1 } & \multicolumn{2}{c}{ Siklus 2 } \\
\hline 1. & AAM & $56 \%$ & Cukup & $68 \%$ & Baik & $84 \%$ & Baik \\
2. & LD & $65 \%$ & Cukup & $72 \%$ & Baik & $87 \%$ & Baik \\
3. & RP & $64 \%$ & Cukup & $73 \%$ & Baik & $78 \%$ & Baik \\
4. & RAW & $65 \%$ & Cukup & $75 \%$ & Baik & $77 \%$ & Baik \\
5. & SN & $63 \%$ & Cukup & $70 \%$ & Baik & $85 \%$ & Baik \\
6. & VS & $50 \%$ & Cukup & $60 \%$ & Baik & $79 \%$ & Baik \\
7. & YAS & $65 \%$ & Cukup & $69 \%$ & Baik & $87 \%$ & Baik \\
8. & MMDDS & $63 \%$ & Cukup & $68 \%$ & Baik & $73 \%$ & Baik \\
Rata-rata & $61 \%$ & Cukup & $69 \%$ & Baik & $81 \%$ & Baik \\
\hline
\end{tabular}

Tabel.2

Perbandingan Skor Observasi Pra Siklus, Siklus I, Siklus II

\begin{tabular}{llllllll}
\hline No & & Nama Siswa & \multicolumn{2}{c}{ Pra Siklus } & \multicolumn{2}{c}{ Siklus 1 } & \multicolumn{2}{c}{ Siklus 2 } \\
\hline 1. & AAM & $35 \%$ & Kurang & $45 \%$ & Cukup & $65 \%$ & Baik \\
2. & LD & $35 \%$ & Kurang & $50 \%$ & Cukup & $70 \%$ & Baik \\
3. & RP & $30 \%$ & Kurang & $50 \%$ & Cukup & $65 \%$ & Baik \\
4. & RAW & $40 \%$ & Kurang & $45 \%$ & Cukup & $65 \%$ & Baik \\
5. & SN & $30 \%$ & Kurang & $45 \%$ & Cukup & $75 \%$ & Baik \\
6. & VS & $40 \%$ & Kurang & $45 \%$ & Cukup & $65 \%$ & Baik \\
7. & YAS & $30 \%$ & Kurang & $50 \%$ & Cukup & $70 \%$ & Baik \\
8. & MMDDS & $40 \%$ & Kurang & $50 \%$ & Cukup & $70 \%$ & Baik \\
\multicolumn{2}{l}{ Rata-rata } & $35 \%$ & Kurang & $48 \%$ & Cukup & $68 \%$ & Baik \\
\hline
\end{tabular}


Dapat dilihat dari tabel perbandingan diatas, peneliti memperoleh skor rata-rata angket 120 dengan persentase $81 \%$ dengan kategori baik. Sedangkan dalam perhitugan lembar observasi 8 subjek memperoleh skor rata-rata 14 dan persentase $68 \%$ dengan kategori baik.

Berdasarkan tujuan dan hasil penelitian yang telah dilaksanakan, selanjutnya peneliti akan membahas mengenai : kondisi kedisiplinan belajar siswa sebelum memperoleh layanan bimbingan kelompok dengan teknik problem solving, Kondisi kedisiplinan belajar siswa setelah memperoleh layanan bimbingan kelompok dengan teknik problem solving, serta pengentasan kedisiplinan belajar siswa melalui layanan bimbingan kelompok dengan teknik problem solving. Sebelum mendapatkan layanan bimbingan kelompok dengan teknik problem solving, 8 siswa subjek penelitian menunjukkan perilaku kurang disiplin dalam belajar disekolah. Pada kondisi awal keadaan 8 siswa subjek penelitian memperoleh skor angket kedisiplinan belajar dengan rata-rata 92 dan persentase $61 \%$ dengan kategori cukup baik. Dan memperoleh skor rata-rata lembar observasi 7 dan persentase $35 \%$ dengan kategori kurang baik.

Setelah tindakan bimbingan kelompok dengan teknik problem solving pada siklus I, yang dilaksanakan pada hari Rabu, 24 Juli dan Kamis, 25 Juli 2019 di ruang BK Sekolah Menengah Atas Veteran 1 Sukoharjo Tahun Pelajaran 2019/2020. Peneliti memperoleh hasil angket kedisiplinan belajar siswa dengan skor rata-rata 103 dan persentase 69\% dengan kategori baik. Sedangkan dalam perhitungan lembar observasi 8 subjek memperoleh skor rata-rata 9,5 dan persentase $48 \%$ dengan kategori cukup baik. Pada layanan bimbingan kelompok siklus I, peneliti mengambil topik menyontek dan membolos. Peneliti mengambil tema tersebut karena dilihat dari observasi awal sebelum penelitian dan dari hasil angket masih banyak siwa yang sering menyontek saat adanya ulangan harian. Ditemukan juga siswa yang membolos atau tidak masuk tanpa keterangan. Sehingga perlu diberi pengertian lebih kepada siswa materi mengenai masalah yang mereka alami tersebut untuk kemudian dicari solusinya dalam kegiatan bimbingan kelompok. Setelah layanan bimbingan kelompok pada siklus satu, peneliti melihat pada hasil observsi bahwa siswa sudah mengalami peningktan. Namun peningkatan tersebut masih rendah dan dari 8 siswa subjek penelitian masih terlihat beberapa kali melakukan pelanggaran tata tertib yang ada disekolah. Karena hasil perubahan perilaku dari angket dan lembar observasi kedisiplinan belajar di siklus I belum mencapai indikator kinerja, maka perlu diadakan tindakan layanan bimbingan kelompok teknik problem solving pada siklus II.

Tindakan layanan bimbingan kelompok teknik problem solving pada siklus II, yang dilaksanakan pada hari Senin, 29 Juli dan Selasa, 30 Juli 2019 di ruang BK Sekolah Menengah 
Atas Veteran 1 Sukoharjo Tahun Pelajaran 2019/2020. Peneliti memperoleh hasil angket kedisiplinan belajar siswa dengan skor rata-rata 121 dengan persentase $81 \%$ dengan kategori baik. Sedangkan dalam perhitungan lembar observasi 8 subjek memperoleh skor rata-rata 14 dan persentase $68 \%$ dengan kategori baik. Pada layanan bimbingan kelompok siklus II, peneliti mengambil topik disiplin dalam belajar dan pentingnya disiplin dalam kehidupan sehari-hari. Peneliti mengambil tema tersebut untuk memberikan pemehaman lebih mendalam lagi kepada siswa mengenai kedisiplinan belajar yang sudah baik saat siklus I. Dalam siklus II ini penelit juga menmbahkan vidio yang berkaitan dengan materi agar anak tidak bosan dan lebih mengerti mengenai materi bimbingan kelompok yang diberikan peneliti dan menjadi tahu contoh nyata dalam kehidupan sehari-hari.

Dilihat dari hasil observasi, peneliti juga melihat seluruh siswa subjek penelitian sudah baik dalam mematuhi tata tertib sekolah, tidak ada yang membolos dan menyontek lagi. Hanya satu atau dua siswa yang masih terlambat masuk kelas saat pergantian jam pelajaran. Namun jika dilihat dari hasil lembar observasi, seluruh siswa sudah mencapai indikator kinerja lembar observasi yang ditentukan oleh peneliti yaitu minimal 65\% dengan kategori baik. Dalam penelitian ini peneliti menggunakan metode problem solving. Menurut Romlah (2006: 93) problem solving adalah teknik pemecahan masalah merupakan suatu proses kreatif dimana individu menilai perubahan yang ada pada dirinya dan lingkungannya, dan membuat pilihan-pilihan baru, keputusan-keputusan atau penyesuaian yang selaras dengan tujuan dan nilai hidupnya. Teknik problem solving mengajarkan pada individu bagaimana memecahkan masalah secara sistematis. Manfaat teknik problem solving menurut Djamarah (2006: 133) bimbingan kelompok teknik problem solving dapat membiasakan para siswa menghadapai dan memecahkan masalah secara terampil, apabila menghadapi permasalahan didalam kehidupan keluarga, bermasyarakat dan bekerja kelak, metode ini merangsang pengembangan kemampuan berfikir siswa secara kreatif dan menyeluruh, karena dalam proses belajarnya siswa banyak melakukan mental dengan melihat permasalahan dari berbagai segi dalam rangka pemecahan siswa lebih aktif menyampaikan pendapat untuk menilai perilaku pada dirinya dan membuat suatu solusi yang sesuai dengan dirinya sendiri.

Teknik problem solving dapat membiasakan para siswa dalam memecahkan masalah kedisiplinan belajar disekolah dan membuat solusi sendiri sesuai dengan kemampuan dan keadaan dirinya. Anggota kelompok menjadi mengerti bagaimana menyelesaikan masalah secara sistematis sesuai langkah-langkah problem solving yaitu : 1. mencari masalah yang jelas untuk dipecahkan, 2. Mencari data yang dapat dipergunakan untuk memecahkan masalah tersebut dengan berdiskusi, 3. Menetapkan jawaban sementara dari masalah tersebut, 4. Menguji kebenaran jawaban sementara tersebut, 5. Menarik kesimpulan. 
Dari hasil penelitian dapat dilihat adanya peningkatan kedisiplinan belajar siswa. Karna dengan adanya bimbingan kelimpok teknik problem solving, siswa menjadi lebih mengerti faktorfaktor apa saja yang menyebabkan siswa tidak disiplin dalam belajar dan bagaimana cara mengatasi masalah kedisiplinan belajar dari materi yang telah didapat dari kegiatan bimbingan kelompok. Siswa juga mengetahui pentingnya kedisiplinan dalam kehidupan sehari-hari dari video yang diberikan peneliti saat kegiatan bimbingan kelompok.

Hal ini dapat dibuktikan bahwa ketika proses evaluasi menggunakan angket kedisiplinan belajar siswa, siswa menunjukkan peningkatan kedisiplinan belajar dari kategori cukup baik menjadi baik. Dilihat juga dari hasil observasi yang dilakukan peneliti, perilaku siswa menunjukkan peningkatan kedisiplinan belajar dari kategori kurang baik menjadi baik. Jadi dapat disimpulkan bahwa penelitian ini sudah mencapai tujuan penelitian yaitu : melalui bimbingan kelompok teknik problem solving dapat meningkatkan kedisiplinan belajar siswa Kelas XI IPS Sekolah Menengah Atas Veteran 1 Sukoharjo Tahun Pelajaran 2019/2020.

\section{Simpulan}

Berdasarkan pembahasan dari hasil penelitian pada siswa kelas XI IPS Sekolah Menengah Atas Veteran 1 Sukoharjo Tahun Pelajaran 2019/2020 terdapat peningkatan kedisiplinan belajar siswa dari perhitungan angket, kedisiplinan belajar siswa sebelum mendapatkan layanan bimbingan kelompok dengan teknik problem solving berada pada kategori cukup baik dengan rata-rata 92 dan persentase $61 \%$. Setelah mendapat layanan bimbingan kelompok dengan teknik problem solvin, $g$ kedisiplinan belajar meningkat dalam kategori baik dengan perolehan rata-rata 121 dengan persentase $81 \%$.

Dan berdasarkan observasi yang dilaksanakan peneliti, kedisiplinan siswa sebelum mendapat layanan bimbingan kelompok dengan teknik problem solving berada pada kategori kurang baik dengan ratarata 7 dan persentase $35 \%$. Setelah mendapat layanan bimbingan kelompok dengan teknik problem solving kedisiplinan belajar meningkat dalam kategori baik dengan perolehan rata-rata 14 dan persentase 68\%. Dapat disimpulkan bahwa : layanan bimbingan kelompok dengan teknik problem solving dapat meningkatkan kedisiplinan belajar siswa kelas XI IPS Sekolah Menengah Atas Veteran 1 Sukoharjo. 


\section{DAFTAR PUSTAKA}

Asrian Dani Aliya, Putri Eka Dona. (2010). Vol.3. No.2. Jurnal Psikologi. Sikap Ayah dan Ibu Tehadap Kekerasan oleh Guru. Diakses pada tanggal 25 januari, pukul 12.30. Depok : $\begin{array}{lll}\text { Universitas } & \text { Gunadarma. } & \text { Retrieved }\end{array}$ http://ejournal.gunadarma.ac.id/index.php/psiko/article/view/235.

Arikunto, Suharsimi. (2010). Penelitian Tindakan. Yogyakarta : Bumi Aksara.

Djamarah, Saiful Bahri. (2006). Strategi Belajar Mengajar. Jakarta : PT Rineka Cipta.

Ismail. (2011). Penelitian Pendidikan. Sukoharjo : UNIVET BANTARA PRESS.

Ismail, Triyanto Bambang. (2011). Pedoman Menulis Skripsi (Edisi Revisi). Sukoharjo : UNIVET BANTARA PRESS.

Romlah, Tatiek. (2006). Teori dan Praktek Bimbingan Kelompok. Malang : Universitas Negeri Malang.

Rosidah, Ainur. (2016). Vol.2. No.2. Jurnal Fokus Konseling. Bimbingan Kelompok Melalui Teknik Problem Solving Untuk Meningkatkan Penyesuaian Diri Siswa Terisolir. Diakses pada tanggal 7 April, pukul 09.30. Pringsewu : STKIP Muhammadiyah Pringsewu. Retrieved from http://scholar.google.co.id/citations.

Santrock. (2003). Perkembangan Remaja. Edisi Keenam. Jakarta : Erlangga.

Sugiyono. (2014). Metode Penelitian Kualitatif, Kuantitatif Dan R\&D. Bandung : CV

\section{ALFABETA.}

Sutama. (2014). Penelitian Tindakan PTK, PTS dan PTBK. Surakarta : FAIRUZ MEDIA.

Wibowo, NAK., Maulana, MA \& Susanto, B. (2019). PENGARUH LAYANAN BIMBINGAN KELOMPOK TEKNIK ROLE PLAYING TERHADAP INTERAKSI SOSIAL PADA SISWA.

Jurnal Bimbingan Konseling, 1(1). Retrieved from http://journal.univetbantara.ac.id/index.php/Advice. 